\title{
PERANCANGAN SISTEM RESERVASI GEDUNG DAN AULA BERBASIS WEB DI WILAYAH BANJARMASIN
}

\author{
Agus Setiawan, M.Kom ${ }^{(1)}$, Agus Alim Muin, M.Kom ${ }^{(2)}$, Budi Ramadhani, M.Kom ${ }^{(3)}$ \\ ${ }^{1}$ Fakultas Teknologi Informasi, UNISKA \\ Email : agusteknik90@gmail.com \\ ${ }^{2}$ Fakultas Teknologi Informasi, UNISKA \\ Email : agusalimmuin@gmail.com \\ ${ }^{3}$ Fakultas Teknologi Informasi, UNISKA \\ Email : budiramadhani@gmail.com
}

\begin{abstract}
ABSTRAK
Gedung dipilih berdasarkan kapasitas ruang, fasilitas umum, dan fasilitas khusus, lokasi gedung, luasnya halaman dan lain-lain. Banyak orang memilih menggunakan gedung untuk melaksanakan suatu event karena disesuaikan dengan besar kecilnya suatu event tersebut. Hal yang sering menjadi faktor pertimbangan bagi penyewa dalam memilih gedung yang tepat adalah lokasi gedung, kapasitas ruang, fasilitas yang tersedia (panggung, meja, kursi, toilet, daya listrik dan air pam), halaman parkir yang memadai, kondisi di lingkungan sekitar, dan Manajemen waktu penyewa. Kendalanya terkadang sebelum memilih gedung, penyewa harus ekstra fisik untuk survey ke beberapa tempat atau gedung, karena terkadang tidak ada yang tahu koordinasi waktu penggunaan gedung tersebut antara gedung yang satu dengan gedung lainnya. Dengan adanya sistem ini diharapkan menjadi informatif dan memudahkan bagi penyewa dalam mengakses seluruh informasi mengenai gedung-gedung yang mereka inginkan mulai dari mengelola seluruh informasi yang diperlukan bagi penyewa, mulai dari jarak terdekat, budget, kapasitas, fasilitas penunjang dan waktu kosong yang bisa di booking penyewa
\end{abstract}

Kata Kunci : Gedung, Aula, Penyewa, Kapasitas, Budget, Fasilitas, Booking, Sistem

\section{PENDAHULUAN}

Bangunan gedung tertentu adalah bangunan gedung yang digunakan untuk kepentingan umum. Misalnya digunakan untuk event-event tertentu, gedung dipilih berdasarkan kapasitas ruang, fasilitas umum, dan fasilitas khusus, lokasi gedung, luasnya halaman dan lain-lain. Banyak orang memilih menggunakan gedung untuk melaksanakan suatu event karena disesuaikan dengan besar kecilnya suatu event tersebut. Hal yang sering menjadi faktor pertimbangan bagi penyewa dalam memilih gedung yang tepat adalah [1] lokasi gedung, [2] kapasitas ruang, [3] fasilitas yang tersedia (panggung, meja, kursi, toilet, daya listrik dan air PAM), [4] halaman parkir yang memadai, [5] kondisi di lingkungan sekitar, dan [6] Manajemen waktu penyewa. Kendalanya terkadang sebelum memilih gedung, penyewa harus ekstra fisik untuk survey ke beberapa tempat atau gedung, karena terkadang tidak ada yang tahu koordinasi waktu penggunaan gedung tersebut antara gedung yang satu dengan gedung lainnya. Dalam hal ini khususnya di Banjarmasin belum adanya sistem yang mengelola informasi yang berhubungan dengan gedung yang ada di Banjarmasin, misalnya daftar gedung mana saja yang sudah di booking pada 
tanggal-tanggal tertentu, dan klasifikasi gedung-gedung mana saja yang mempunya kapasitas mulai dari terkecil sampai terbesar, dan fasilitas-fasilitas penunjang apa saja yang ada pada masing-masing gedung tersebut. Dari pembahasan tadi peneliti mempunyai gagasan untuk membuat suatu sistem yang mengelola sewa gedung atau bangunan berbasis web atau online untuk wilayah Banjarmasin bagian utara, sehingga bisa mengelola seluruh informasi yang diperlukan bagi penyewa, mulai dari jarak terdekat, budget, kapasitas, fasilitas penunjang dan waktu kosong yang bisa di booking penyewa. Dengan adanya sistem ini diharapkan menjadi informatif dan memudahkan bagi penyewa dalam mengakses seluruh informasi mengenai gedung-gedung yang mereka inginkan.

\section{RUMUSAN MASALAH}

Berdasarkan latar belakang tersebut dapat dirumuskan masalah bahwa perlunya dibuat sebuah sistem yang mengelola tentang informasi informasi yang terkait dengan penyewaan gedung atau bangunan di kota Banjarmasin yang berbasis web.

\section{TUJUAN DAN TARGET LUARAN}

Adapun tujuan dari penelitian ini adalah memudahkan warga Banjarmasin dalam mencari informasi mengenai gedung atau bangunan yang ingin digunakan untuk acara - acara penting.

Target luaran wajib dan tambahan dalam pembuatan penelitian ini yaitu akan dipublikasikan dalam jurnal lokal yang mempunyai ISSN atau jurnal nasional terakreditasi dan sesuai bidang ilmu seperti Jurnal Techonogia

\section{METODE PENELITIAN}

Pada penelitian ini menggunakan beberapa metode pengumpulan data sebagai berikut :

a. Metode Observasi

Observasi atau pengamatan merupakan salah satu teknik pengumpulan data atau fakta yang cukup efektif untuk mempelajari suatu sistem. Observasi adalah pengamatan langsung para pembuat keputusan berikut lingkungan fisiknya atau pengamatan langsung suatu kegiatan yang sedang berjalan. Pada tahap ini melakukan pengamatan terhadap gedung - gedung yang terdaftar di Banjarmasin, dilakukan observasi secara menyeluruh mulai dari daftar lokasi-lokasi gedung, fasilitas yang tersedia, sampai biaya sewa.

b. Metode Wawancara

Wawancara merupakan salah satu teknik pengumpulan data yang penting dan banyak dilakukan dalam pengembangan sistem informasi. Wawancara memungkinkan analis sistem sebagai pewawancara untuk mengumpulkan data secara tatap muka langsung dengan orang yang diwawancarai. Adapun orang-orang yang diwawancarai adalah petugas pengelola gedung dan 2 orang sample pihak penyewa

\section{ANALISA HASIL DAN PEMBAHASAN}

\section{Hasil Pengumpulan Data}

a. Metode Observasi

Observasi melakukan analisa melaui pencarian di google dengan keyword "sewa gedung banjarmasin", "reservasi gedung banjarmasin", atau "gedung banjarmasin". Didapatkan hasil tidak ada sistem berbasis website 
untuk mengelola sistem sewa

Gambar 1 pemesanan

gedung di Banjarmasin.

b. Metode Wawancara

Wawancara dilakukan kepada pengelola gedung dan aula

\section{Implementasi sistem}

a. Form tampilan awal

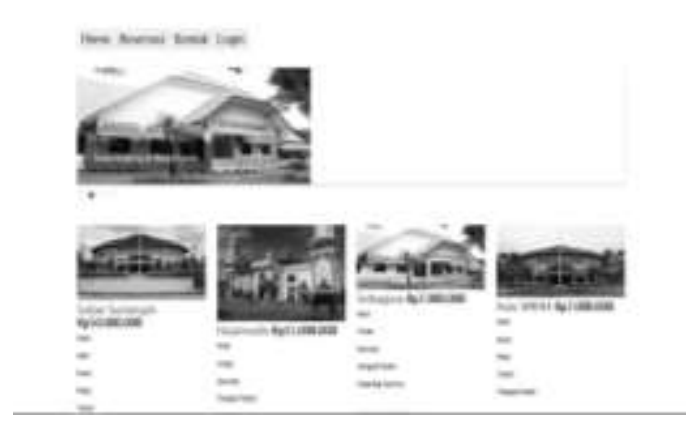

Gambar 1 Form tampilan awal

b. Form reservasi

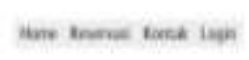

SHUKAN Boosas croias

Gambar 2 reservasi

c. Form pemesanan

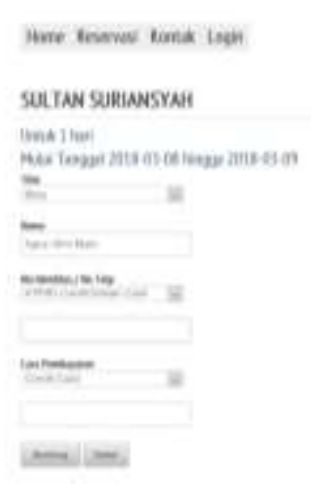

\section{PENUTUP}

\section{KESIMPULAN}

Kesimpulan dari penelitian yang telah dilakukan adalah belum ada aplikasi berbasis online yang mengkoordinasi tentang sewa gedung di Banjarmasin.

\section{Saran}

Saran dari penelitian yang telah dilakukan adalah sebagai berikut :

1. Desain sangat sederhana, maka untuk kedepannya bisa lebih dibuat menarik

2. Sistem yang dibuat masih sangat sederhana yang berdasarkan ruang lingkup yang ada, tapi tidak menutup kemungkinan pengembang lain bisa menambahkan beberapa form sesuai keperluan

\section{DAFTAR PUSTAKA}

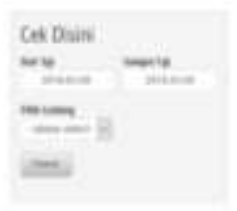

1] Abdul Kadir. 2010. Mudah Mempelajari Database MySQL. Yogyakarta:Andi Offset

2] Kendall, Kendall. 2010. Analisis dan Perancangan Sistem. Jakarta : Penerbit Indeks.

3] Arief, M. Rudyanto. 2011. Pemrograman Web Dinamis Menggunakan PHP dan MySQL. Yogyakarta: Andi Offset

4] Jogiyanto, HM. 2005. Analisis dan Desain Sistem Informasi: Pendekatan Terstruktur, Teori dan Praktik Aplikasi Bisnis. Yogyakarta:Andi Offset 
5] Kusrini. 2007. Strategi Perancangan dan Pengelolaan Basis Data. Yogyakarta: Andi Offset

6] Rangga Andriyanto, 2004, Membuat Website Menggunakan Mysql, Andi Offset, Yogyakarta, 2011
7] Peranginangin, K. (2006). Aplikasi $W E B$ dengan PHP dan MySQL. Yogyakarta: ANDI. 